\title{
Religion and The Drnamics of Right Wing Populism in Poland: Impacts, Causes, Prospects
}

David Herbert, Kingston University London

\begin{abstract}
This paper synthesises recent research on the dynamic between religion and right wing populism (RWP) in Poland by investigating their interplay across four socio-political fields: immigrant and refugee reception, conditions for religious minorities (Antisemitism and Islamophobia), gender relations and LGBT rights. It focuses on the roles of both discursive religion (public discourses which use and are shaped by religion) and of institutional religion, especially the Polish Catholic Church (PCC), while acknowledging other factors shaping the electoral success of the Prawo i Sprawiedliwość (Law and Justice) party, which has enabled a RWP agenda to be implemented by government. Such factors include the role of media (especially some Catholic media), social media, and welfare policy. It argues that where official Catholic teaching clearly opposes RWP stances (e.g. on refugees and interfaith relations) the leadership of the PCC has attempted to restrain RWP mobilisation. However, where official teaching aligns more closely with RWP ideology (e.g. on gender and sexuality) opposition has been largely limited to liberal minorities within the church. It concludes by surveying the developing collaboration of opposition movements.
\end{abstract}

KEYWORDS: right wing populism, discursive religion, Polish Catholic Church, antisemitism, Islamophobia, LGBT rights, immigration, gender, othering, polarisation.

\section{Introduction: Responses to the Refugee Crisis and Immigration}

Closing doors is not the solution... We all have the duty of welcoming our brother who flees from war, hunger, or violence. (Pope Francis, 2016)

A good Christian is one who helps, [but] not necessarily by accepting refugees. (Elżbieta Witek, PiS spokesperson, quoted in Cienski 2017)

Migrations are dynamic, common and - as the history of the world shows - unavoidable, but in the context of socio-demographic situation in our country they are even beneficial. Large Polish cities for years have been open to migration processes and diversity of inhabitants...It is in our common, broadly understood interest that migrations are managed responsibly and safely at the 
local level so that we create socially coherent cities, minimizing the threats related to ghettoization, separation, poverty and exclusion of new inhabitants. (Declaration of Mayors on the Cooperation of the Union of Polish Metropolises Concerning Migration, in Szpak 2019: 1165)

These quotations suggest something of the diversity of opinion in Poland concerning the 2015-16 refugee 'crisis' and immigration more broadly, and of the roles and uses of religion in Polish political discourse. While Pope Francis' statement has been echoed by official Polish Catholic sources (Narkowicz 2018: 361), the current government has interpreted Christian teaching rather differently, as their spokesperson's comment suggests. Polish government discourse also contrasts with the approach of city authorities faced with the practical challenges of dealing with modest (in comparative European terms) but increasing immigration (second and third quotations). For while the PiS (Prawo i Sprawiedliwość, Law and Justice Party) government (2015-) is rhetorically hostile to most forms of immigration, it has failed to produce national policies to deal with its practical challenges, so as immigrant numbers have grown during its period in office, the burden of response has fallen to cities:

In October 2018 the number of migrants who were granted the right of residence in Poland reached about 360,000... in October 2017 it was about 30,800 and 23,700 in 2016. (migracje.gov. pl.en quoted in Szpak 2019: 1061)

In response to the 'refugee crisis' of 2015-16 the Polish Catholic Church (PCC)'s official leadership, the Bishops' Conference, followed the papal call by issuing 'several statements calling for assistance to churches in the Middle East ... [and] to refugees from Iraq and Syria' (Pędziwiatr 2018: 466). In the build up to World Youth Day in 2016 they followed this up with a practical policy suggestion to introduce Italian style 'humanitarian corridors' to allow refugees safe passage to countries further north and west with more resources to help refugees; however, 'after the refusal of the government to relocate any refugees to Poland, and numerous Islamophobic statements by members of the government, the initiative was abandoned at the end of 2016.' (ibid., 467). As we shall see further below in the section on Antisemitism and Islamophobia, these official responses are in line with theological teaching in the Catholic Church since the Second Vatican Council, both on humanitarianism and interfaith dialogue. But in the Polish public sphere they have tended to get shouted down by more strident voices drawing on a xenophobic Catholic nationalism:

Some Catholic media outlets ... associated with the conservative wing of the Church - such as the website Fronda.pl and the bimonthly glossy magazine Polonia Christiana, online at PCh24.pl - have significantly contributed to stereotypical portraits of refugees, Arabs and Muslims. They have served as important 'thickening agents' of the thin populist ideology that considers society to be ultimately separated into two homogeneous and antagonistic camps ... and politics to be the expression of the 'general will' of the people. (ibid. 468).

Immigration is just one social field affected by right-wing populism in Poland. Other areas include religious minority rights, women's rights - especially reproductive rights - and LGBT rights. Furthermore, under the PiS government the independence of public service broadcasting, the judiciary and the civil service have been challenged by legislative changes introduced as part of a concerted effort to change the composition of key national institutions viewed as 'too liberal' (Marcinkiewicz 2016: 474).

As with immigration, the response and role of the Christian population and institutions across these social fields is complex $-90 \%$ of the Polish population may identify as Catholic, but the church does not speak with one voice. Drawing on recent research, this paper will survey the impact of right wing populism across these fields, investigating the causes of right wing populist influence, examining the extent to which religion is mobilised both as a discursive resource in its support ('discursive religion', Herbert 2003: 24-7) in the public 
sphere, not under the control of PCC, and as 'institutional religion' (ibid.) - the PCC and other religious actors. The central research questions addressed are:

1. What is the influence and effect of right wing populism across key social fields in Polish society, including the rights and lives of religious minorities (Muslim and Jewish), gender relations (especially gender equality initiatives and reproductive rights), and LGBT groups?

2. What is the role of religion in the mobilisation of right wing populism?

3. What has caused the increase in RWP influence across these social fields in Poland?

4. How have opposition groups responded, and what are the prospects for change?

\section{Historical Context from Partition to PiS: Catholicism, National Identity and Populist Radical Right Mobilisation in Poland}

The European Social Survey (ESS, 2016) shows that in a continent where a majority amongst young people (aged 16-29) in many countries say they have no religion (e.g. the UK and the Netherlands in Western Europe, and Poland's neighbours, the Czech Republic and the Eastern provinces of Germany), fully $84 \%$ of Polish young people identify as religious. Furthermore, as Bullivant (2018) notes, not only does Poland 'have a very high proportion of Catholic affiliates, but they exhibit remarkably high levels of actual practice: almost half attend Mass at least weekly, and only 3\% never attend'. Thus, regular Catholic ritual practice remains a strong aspect of shared social life in Poland. This strength of support for Catholic rituals, and the communal power of religion it attests to and reinforces, needs to be understood in the context of a distinctive national history.

Partitioned between Russia, the Austro-Hungarian Empire and Prussia for the long nineteenth century (1772-1918), the Polish language and Catholic Church (PCC) became the twin pillars of national identity. Occupied by Nazi Germany (1939-1945), Poland emerged devastated from World War II, shorn of its religious diversity (Jews lost to the Holocaust and emigration, German Lutherans fled West ahead of the Red Army) and with a Communist regime under Soviet influence which suppressed Polish hopes for sovereignty. In this context with a 96\% Catholic population and political dissent stifled, the PCC became both the institutional and symbolic centre of independent Polish national identity.

An illustrative case is the commemoration of the millennium of Polish nationhood in 1966. While the state celebrated by portraying the communist system as the crown of the road traversed by the Polish nation through history towards freedom and progress' (President Gomułka, in Kubik 1994: 112), the PCC launched a decade long tour (1956-66) to all Polish parishes of the national icon the black Madonna of Częstochowa, a move which precipitated a 'massive returns to the sacramental life' (ibid,) which 'defined the cultural conflict between church and state for decades to come' (ibid.:111). This cultural frame was tapped into by the Solidarity independent union movement, as it began its nine-year struggle for Polish independence:

The initial public presentation of Solidarity in the Gdansk shipyards in August 1980 - with its crosses, flowers, religious pictures, Masses - [was] instantly comprehensible to a mass public. Such a religious/historical format ... enhanced Solidarity's potential for mass mobilisation. (Osa 1997: 352)

The idea of Poland, sustained by the church, standing alone abandoned by allies and occupied and divided by enemies is thus one with strong historical resonance, and provides 
an interpretative frame which, while not exclusive to the populist right, has been powerfully mobilised by it, and especially by the PiS.

On the side of the PCC, its role as the symbolic dynamo of opposition placed it in a powerful position to shape the post-Communist settlement in 1989. But a role which had proved effective in opposition was arguably less suited to functioning in a democracy, especially the liberal form of democracy defined by the protection of individual minority rights. For the PCC used its powerful position and popular support to embed itself in state institutions such as education (especially religious education), and to push through legal change (including increasing restrictions on abortion), against majority public opinion. In the early 1990s this led to clashes with the Ombudsman for Citizen's rights, who repeatedly warned of the emergence of 'denominational' or 'parachurch' state in Poland, for example:

The church is actually interfering with all three spheres of power: legal, executive and court. I am afraid that we are standing at the gateway of a denominational state (1993 in Pawlik 1995: 34)

Commenting on these developments Krzemiński argues:

The Church ... very quickly began to define sharply its moral and political message, ceasing to be an open space for people with different, sometimes contradictory attitudes ... the Church very quickly ... undermine[d] its undoubted accomplishments in favour of trying to secure political influence in the new state (2018: 87)

The 1990s also saw the re-emergence of forms Polish nationalism which reached back to Poland's pre-communist history, for example influenced by the ideas of Roman Dmowski, in which the Church and nation are seen as inextricably intertwined to the exclusion of others viewed as intrinsically untrustworthy and treacherous, including Jews, foreigners and liberals (ibid. 95). In this discourse is found the characteristic polarizing rhetoric of populist mobilization - the people, perceived as organically united and of one will, in this case bound by Church and nation, against the others - liberal 'elites' and the media, foreigners, other religions and minorities. As we shall see, this discourse fits the classic definition of radical right populism as defined by Mudde, which holds that:

[S] tates should be inhabited exclusively by members of the native group ('the nation') and that non-native elements (persons and ideas) are fundamentally threatening to the homogenous nation-state (Mudde, 2007: 19)

\section{Factors Empowering the PiS; Radio Marjya, Social Media, Welfare Policy and Religious Voters}

A key disseminator of the populist and ultra-nationalist discourse which emerged in the 1990s has been the Radio Marjya (RM) media group which, across multiple platforms, has pushed for an exclusivist Polish nationalism rooted in popular Catholicism. Led by a Redemptorist monk, Father Tadeusz Rydzyk, the 'father-director', the radio station Radio Marjya (founded 1994) has contributed to religious nationalism becoming part of the dominant media frame. By 2007:

The media outlets constituting the Radio Maryja Group ... include[d] a daily newspaper (Nasz Dziennik, 'Our Daily'), a TV station (TV Trwam), a private university in Toruń ('Wyższa Szkoła Kultury Społecznej i Medialnej', College of Social and Media Culture), a charitable foundation 
(Lux Veritatis), a museum and an array of other projects-all with a strongly nationalist-Catholic profile, often in conflict with the PCC's official position (Fras 2007: 34)

The RM group has played a key role in propagating and maintaining a populist, socially conservative discourse in Poland, especially the field of gender relations and female autonomy:

Promoting itself as 'the Catholic voice in your home', ... Radio Maryja ... skilfully utilizes the new technologies and tools of the open market to revive the socialist cult of leadership and to mobilize paternalistic ideology in order to convey hegemonic teachings about the meanings of family, gender roles, sanctioned heteronormativity and proper marital procreativity (Marcianak 2009: 173)

Rydzyk actively participated in the creation of an ultra-nationalist political party, the League of Polish Families in 1999, and later switched his allegiance to the more electorally successful PiS, which led the ruling coalition from 2005-7 and has formed a majority government in Poland since 2015. While its listeners have often been dismissed as ignorant, rural and elderly by critics, and Rydzyk ridiculed, Radio Maryja (RM)'s audience share has at times reached a significant proportion of the population - for example, the Polish Statistical Institute estimates and increase from $4 \%$ to $15 \%$ in the years 2008 to 2011 (CBOS 2011), although this had dropped to $1.9 \%$ again by 2015 (Krzemiński 2018: 99).

But, as Krzemiński argues, the RM group's main influence does reside in its share of radio audience, but rather in its role in the dissemination of an ultra-nationalist outlook through its multiple organs, from local support groups to educational and media institutions, and in the number of bishops supportive of the movement, despite opposition from others:

The real significance of RM does not consist in the number of listeners it has ... [but rather in] the acceptance and support of Polish Bishops for the views expressed by RM, and with the political role of the radio station as well as Fr. Rydzyk's entire media conglomerate. (ibid. 100)

It is important to note that the activities of RM have been challenged by the PCC's senior leadership. Cardinal Glemp, Archbishop of Warsaw from 1981-2006 repeatedly tried to reign it in but was unsuccessful in part due to 'widespread support for RM amongst the Polish bishops' (Krzemiński 2017: 93). Only after the intervention of Pope Benedict XVI, in which he urged the Catholic media in Poland to 'respect the autonomy of the political sphere and the unity of the episcopate', was a Policy Board including bishops established to oversee the RM group's activities, but this too has had limited impact (ibid.).

Still, while the role of RM group has been significant in circulating ultra-nationalist views, it is not enough to explain the electoral success of PiS in the 2015 election, when it took $37.6 \%$ of the national vote, enough to win it a majority of Parliamentary seats, a vote share increased to $44 \%$ in 2019 . Other key factors include successful use of social media to target voters using its strongly polarising discourse, which capitalised (in 2015) on anxieties about national security (heightened by the Ukraine crisis) and fears around immigration also entwined with security, especially from Muslim societies in response to the European 'migrant crisis' of 2015 (despite the low numbers of asylum applicants to Poland - fewer than 150 applicants in 2015, Narkowicz 2018, 358).

Another important factor was the promise of more generous social provision, especially the Family 500 Plus programme, which offered 500 złoty (c. 120 Euro) per month per child to families to support their second and subsequent children. In a country with the highest 
proportion of people in temporary jobs in Europe (Eurostat 2014), this protection from employment precarity proved particularly attractive.

Analysts also highlight the role of religious voters in supporting the PiS in the 2015 election (Marcinkiewicz 2016: 471). Survey data shows that frequent religious participation is strongly correlated with voting PiS $-76 \%$ of intending PiS voters attended mass once a week or more, compared around $40 \%$ for major rival political parties (ESS 2014). However, unscrambling what this means in terms of the role of religion the PiS victories in 2015 and 2019 is, as indicated above, not straightforward. There are differences of opinion amongst Polish Catholics, both between an 'open' or liberal Catholic press (e.g. Znak, Tygodnik Powszechny and Więź) and the nationalist RM media group, and between church leaders keen to align with official teaching seeking to restrict the influence of the RM group but hampered by opposition from within their own ranks. However, the association of high mass attendance with voting PiS supports the analysis of Narkowicz that amongst the laity supporters of:

'Closed Catholicism', [which] is the much larger and more influential movement of reactionary traditionalist right-wing Catholicism that has more in common with the current government (2018: 362)

...outnumbers the supporters of 'Open Catholicism' who have 'historically engaged in critical debates with the secular left and still contribute to the public sphere through magazines ... that resist a reactionary Catholicism in Poland' (ibid.).

In the context of this complex dynamic in relation to RWP in the religious field, we turn to the impact of RWP mobilisation on other social fields, beginning with religious minorities.

\section{Varieties and Dynamics of Antisemitism and Islamophobia in Poland}

The Polish-language internet is overflowing with hate speech, especially of the anti-Semitic variety. (Gerbert 2014: 99)

The imagined threat of a Muslim terrorist arriving from Syria disguised as a refugee has dominated public discourse on refugees in Poland. (Narkowicz 2018: 358)

Despite the Catholic Church's official teaching, which recognises the salvific efficacy of other religions and calls for dialogue (Nostra Aetate), and despite a unique initiative by the Council of Bishops to develop such dialogue in Poland:

the Dzien Islamu (Day of Islam), celebrated for the first time in January 2001. ... consists of numerous interfaith events (conferences/seminars and interfaith services) is held every year on 26 January in different parts of the country. (Pedziwiatr 2018: 463)

... public opinion polls show anti-Semitic and Islamophobic attitudes to be widespread in Poland, despite the tiny Jewish and Muslim populations. Thus the 2011 census recorded 7353 self-identified Jews in Poland, with current estimates at around 10,000, while Pędziwiatr (2015) estimates the number of Muslims in Poland to be between 25,000 and 40,000. Thus in a 
population of 38.7 million means each group accounts for around or less than $0.1 \%$. This is in stark contrast to public perceptions of the extent of immigration:

The Perils of Perception study carried out in 2016 by Ipsos Mori revealed that Poles believed that their country was inhabited by 2.6 million Muslims and that their number would grow to represent 13 per cent of the total population (5 million people) by 2020. (Pedziwiatr 2018: 465)

In the context of these wildly distorted perceptions, it is perhaps not surprising that a Pew survey in 2016 found 66\% of Poles held an unfavourable attitude towards Muslims living in the country, the third highest in Europe after Hungary (72\%) and Italy (69\%), while a survey of anti-Semitism found that $64.5 \%$ believed moderately or strongly in Jewish conspiracy theories (Jews are a threat to economic well-being of Poles), and $22.5 \%$ believe moderately or strongly in 'traditional' antisemitism, where Jews are seen as a threat to Christian religious culture, beliefs or values (Bilewicz et al., 2013: 825-8).

Alongside these widespread negative beliefs and attitudes, reported attacks on the small Jewish and Muslim populations are increasing (Bujalski 2016); indeed, the tiny Jewish population suffered 98 reported racist attacks in 2012 (Gebert 2014: 97). This is part of rising trend in reported hate crime, up from 194 attacks in 2009 to 886 in 2017 (OSCE 2017). This situation appears not to have been helped by the PiS government, which dissolved the Council Against Racial Discrimination and Xenophobia (the sole government body working against hate crime) and arguably legitimises the far right presence in civil society both by its polarising discourse and active measures such as removing sections on far-right ideology from educational material on hate crimes for police forces (Pedziwiatr 2017; Narkowicz 2018: 388).

While Polish anti-Semitism has medieval roots and a continuous history, manifest after the Second World War in government supported pogroms legitimised by 'modern antisemitism' in the post war period (1948, and as late as 1968), Islamophobia beyond a more generalised Orientalism (assumption of European cultural superiority) appears to be a more recent phenomenon. Clearly, anxieties around terrorism are prominent, as elsewhere (Narkowicz 2018: 358), but cultural resistance to a Muslim presence may be shaped by different factors to those operating in Western Europe. For example, Narkowicz and Pedziwiatr (2017) argue that mosque building was regarded as 'largely unproblematic before the Second World War and during the Communist era'; only recent construction in Warsaw has sparked intense public controversy revealeding 'unprecedented opposition'(ibid.: 441).

In understanding this development Narkowicz and Pedziwiatr (2017) caution against assuming that Islamophobia in Poland will follow a similar trajectory to that in Western Europe, pointing to different historical experiences:

Muslims were not primary (ex) colonial subjects and had different class positions; from the Tatars who were highly regarded in the Polish army to the students from befriended socialist Arab countries during Communism (ibid. 454)

However, they concede that Western European Islamophobic discourses had influenced the rhetoric of their interviewees, local people who had objected to the construction of the Warsaw mosques, for example when they:

applied 'gender exceptionalism' through identifying themselves with a largely imagined gender equal national community - Western Europe - in order to be able to mark Islam and Muslims of discrimination of women. (ibid.: 454)

Yet they argue that Polish Islamophobia differs from Western European forms in being more rooted in religion, particularly when mobilising around common 'Christian' principles 
in order to prevent 'Islamisation of Poland and Europe' (ibid., 455). However, while not assuming the primacy of Western European patterns is doubtless a correct starting point, this point is questionable; the rhetoric of the Islamisation of Europe echoes PEGIDA and other far right groups active in Central and Western Europe. While there are Western European Islamophobic discourses which do not depend on the defence of Christian people/culture (the discourse of Pim Fortuyn and his successors in the Netherlands for example, which draw on a defence of secular and Enlightenment principles in order to combine Islamophobia with a pro-gay stance; Herbert 2013: 47), the defence of Christian people/culture is often invoked in Islamophobic discourses Western Europe. This is so even in Scandinavia where regular religious participation is minimal, occurring because ethnic boundaries are still bound up with religious identification. For example, in Denmark conversion to Islam is regularly seen as crossing an ethnic boundary (Herbert and Hansen 2018).

Furthermore, other sources argue that 'liberal Islamophobic' discourses are also found in Poland, alongside the 'nationalist Islamophobic', as in Western Europe. Thus Bobako (2018) distinguishes between a 'liberal Islamophobia' which is:

[I]s a way to confirm symbolically Poland's belonging to 'the West' and its commitment to the normative project of European modernity, with its affirmation of individualism, human rights, sexual freedom and secularism (ibid., 448)

....and 'the Islamophobia of the resurgent nationalist forces in Poland [which] is ... the outcome of a rejection of this very project, which is perceived as a threat to national political sovereignty and cultural autonomy' (ibid.). Indeed, by appealing the defence of both gender equality and Christian values in their discourse, Narkowicz and Pedziwiatr's interviewees also arguably draw on both. This is not to argue that the balance of appeal to these discourses is even between Poland and, say, the Netherlands - it certainly is not, with the Christian nationalist discourse having stronger appeal in Poland - but rather that both discourses operate in both contexts, depending on the shifting dynamics of 'Othering' - 'secular' Western Europe is on the one hand 'other' in relation to Poland's Catholic nationalist identity, but 'like' in relation to Islam and Muslims.

\section{Homophobia and Right Wing Populism in Poland}

Illiberalism toward sexual minorities has deep roots in many of the new member-states. Communism was deeply conservative culturally, encasing traditional, recently peasant-based social practices in 'neo-Victorianism' (O'Dwyer and Schwartz 2010: 221)

These are ordinary, thoroughly ordinary people: nice $\mathrm{Mr}$ Kowalski from the allotments, $\mathrm{Mr}$ Nowak who goes to the local shop, Mr Wolski from No 6. But with masks instead of their usual faces, which are altered in a nightmarish way, their eyes full of blood, their voices raucous, yelling, "fuck, arse, faggots". The fact that those rosaries, those crosses, those icons of Jesus they're holding up are soiled with filth, interlaced with the ugliest words of all, with linguistic excrement, is an act of blasphemy no Polish bishop will ever condemn. (Dehnel 2019, reporting from the first Pride march in Białystok, July 2019)

Regional party [PiS] officials have ... pushed to declare cities and even entire provinces in the country's conservative southeast "LGBT-ideology free". Activists have counted around 30 such declarations so far. (Noack 2019)

A 2013 report found that 63 percent of LGBT people in Poland agree with the statement that discrimination on the grounds of sexual orientation [is] widespread. (Gebert 2014: 98). Homosexual activity is legal in Poland and LGB people may serve in the military, but LG 
marriage and civil partnerships are not recognised, no specific category of homophobic hate crime exists in law, and homophobic hate speech is not a criminal offence (Godzisz and Knut 2018). Like other parts of former communist Central and Eastern Europe, Poland inherited socially conservative norms from the Communist period, reinforced by the strong traditionalist elements in the PCC.

The pre-and post EU accession periods saw great optimism amongst LGBT activists, with the first Pride parades organised, but already by 2005 (the first PiS (coalition) government was 2005-7) attempts were made to ban the marches and opposition demonstrations officially encouraged (O'Dwyer and Schwartz 2010: 220-1). Official PCC rhetoric has largely resonated with that of the government and right-wing press:

The Polish Bishops' Conference calls non-heterosexual arrangements "completely alien to European civilisation". During Easter mass, the Metropolitan Archbishop of Gdansk condemned the "idol of tolerance". An "LGBT dictatorship" is approaching, warned a recent cover of Do Rzeczy, a right-wing weekly (The Economist 2 May 2019)

In the case of the 2019 Białystok Pride parade from which a participant's testimony was quoted above, the event was held in defiance of Archbishop Tadeusz Wojda's explicit condemnation of the event. The second PiS period of government has seen further intensification of government led homophobic rhetoric, with a particular escalation in the run up to European Parliamentary elections in May 2019. PiS officials deployed the tactic of encouraging cities and provincial authorities to declare 'LGBT ideology-free zones'. While such 'zones' would have no legal status, the intent of curtailing the public display of difference is clear.

\section{Visibility, Othering And Agency}

The rhetoric used to mobilise against a public LGBT presence is worthy of further comment, because it is positioned as not only 'anti-family' - even paedophile (Reuters, 2019) - with proposals to improve school education about sexual diversity described not only as an 'attack on children'- but also as 'foreign', despite the evidently ethnic composition of Polish Pride parade participants. Situating LGBT discourse a 'foreign ideology' reflects a broader positioning of feminist and equalities discourses as alien 'gender ideologies' imported from the West, a discursive position that arguably blends Polish nationalism with Communist antiWestern discourse, situating them as imperialist and aggressive attacks on Polish independence and cultural autonomy. Visible Polish LGBT citizens seem to be experienced by the users of such language as an unwelcome intrusion, an attack on the established social order.

The terms used suggest a dynamic strikingly similar to reactions to the visible signs of Islam - manifest in mosque construction and the wearing of hijab - in cities in Western Europe. As Gőle 2012 observes:

temporary and hidden mosques without a distinctive, recognizable feature in suburban industrial zones, ... do not stir public unrest. It is ... visual religious and cultural difference in the city centers, and the awakening piousness of Muslims that provoke public controversies around mosques across Europe (Göle 2012: 383)

In Göle 's account, 'the 'visibility' of Islam in public is conceptualized as a form of agency ... a manifestation of religious difference that cannot be thought independent of the materiality of culture, namely aesthetic forms, dress codes, or architectural genres'. In the same way, it is the visibility of LGBT identity in Poland's city centres, and the materiality of Pride, that seems to elicit the strongest reactions. It is by coming out of the closet dressed differently that LGBT activists and Muslims seem to most challenge nativist constructions of social order. 
Thus, by conceptualising 'the 'visibility' of Islam in public as 'a form of agency' Göle provides a framework for making sense of antagonistic reactions to novel claims to public presence, whether by French Muslims or Polish LGBT rights activists. For in the claiming the right to be openly present and seen they render visible the exclusive basis of the existing social order, and hence call for its renegotiation - though via a call rooted in a struggle for recognition and equality rather than domination, as the far right reading suggests.

In electoral terms, however, PiS tactic appears to have been successful, with the party strengthening its position in the European Parliament, increasing its seats from 19/51 to 27/52, a majority of seats for the first time. However, by espousing such a divisive rhetoric the PiS has also appears to be galvanising opposition forces. In February 2019 Warsaw's mayor Rafal Trzaskowski signed a declaration in favour of lesbian, gay, bisexual and transgender (LGBT) rights signed by, Warsaw's newly elected liberal mayor, with proposals including 'a shelter in Warsaw, anti-discrimination measures and more sex education in schools', with the Poland's Ombudsman for Human Rights calling for other cities to follow suit (The Economist, 2019). A new left wing party, Wiosna (Spring), led by a former mayor and campaigning on a platform which included legalising gay marriage, took $6 \%$ of the vote in European elections. And mass protests have been organised against measures initially supported by PiS to tighten Poland's already strict abortion laws still further.

\section{Abortion Rights and the Development of Opposition Networks}

Prorefugee, anti-racist, feminist, left-wing and LGBTQ groups have joined together in various initiatives in recent years in what has become a resistance to what is perceived as a climate of hate towards not only ethnic and religious minorities, but to all forms of Otherness (Narkowicz 2018: 369)

One such major galvanising issue in recent years has been the proposal to further tighten Poland's already strict abortion laws to ban abortion in almost all circumstances. Despite a total ban only being supported by $7 \%$ of the population, the Parliamentary arithmetic after the 2015 landslide for the PiS meant that with government backing a proposal by the private Catholic foundation the Ordo Iuris Institute could have become law. This set the scene for one of the most remarkable confrontations in recent Polish history:

On October 3, 2016, cities across Poland were seized by massive demonstrations against new proposals for a total abortion ban in the country. These proposals, first drafted by the Ordo Iuris Institute, a reactionary Catholic foundation, were designed to deny all access to abortion, with no exceptions. The conservative government of the Law and Justice party (PiS), along with the Roman Catholic Church, fully supported the idea. But the women's rights movement that spontaneously emerged in opposition forced ruling-party members in Parliament to abandon the project (Szelegieniec 2018: 45).

This victory of the 'Black Friday Protests' - so-called because of the dark clothes worn by many protesters - was particularly remarkable given the relative weakness of feminist and women's rights movements in Poland since the 1990s (Hall 2019). The movement was enabled by mobilisation on social media platforms and involved significant participation from nonreligious activists. While not explicitly targeted by far right activists in the way that religious and LGBT minorities are, nonreligious - those who profess that they have no religious belief and reject identification with any religious groups - are a growing minority in 
Poland (16\% of aged 16-29, SOURCE), and evidence ${ }^{1}$ suggests this group also feel increasingly marginalised in the nationalist Catholic public environment promoted by the PiS and other far right groups. For example, 'Monika', a 26-year-old woman from Warsaw comments:

Well, now the church is getting more and more involved with politics... Recently there were some huge protests about the abortion ban, the church wanted politicians to pass this law. There were some huge protests around here, so, I mean, if this would pass, that would affect my life a lot, like other people in Poland. It could mean that church would say, "Well, we can now do anything. If we can make politicians pass the law we want", then it would start to affect my life a lot.

Monika's nonreligious identity became highlighted and potentially politicised when it is confronted by challenges which she experiences as intruding on her personal choices. Polling data suggests Monika's stance on this issue is typical of young nonreligious; data from 2016 shows that nonreligious have amongst the highest support for pro-choice positions in the abortion debate in Poland:

support for abortion was strongest among groups with left-wing political sympathies (73 percent to 91 percent) and the non-religious (81 percent to 94 percent) (Szelegieniec 2018: 50)

Furthermore, the support carried through into strong support for the Black Protests:

In general, 58 percent of Poles said they supported the protests, while 26 percent opposed them. Politically, the strongest support came from people who identified as left-wing (76 percent) and nonreligious (78 percent) (ibid. 55)

Furthermore, some nonreligious had prominent leadership roles within the Black Protest movement. Basia (early 30s, from Wrocław) for example, helped to organise both the Black Protests and the Women's Strike that followed in 2017. Indeed, it was in the context of organising for the Black Protests that Basia developed a sense that a stronger voice was needed for people who wanted to opt out of church control, so she developed a Facebook group to support people going through the socially challenging and bureaucratic apostasy process:

What I realised during the Black Protests is that there's a group of people in Poland who need a speaker, who need somebody to speak their mind, to say we are against this and that and we can break our contract with the church.

Basia argues that the abortion issue in particular is radicalising the anticlerical aspect of the Polish opposition:

Step by step and slowly, it's turned to the last focus on the abortion thing, because the topic is returning on and on, because once it is stopped, then the government tries again, because they are full of religious fanatics, and they are supported very strongly by the religious politics, and they give them money openly as well, which also makes the people ... I mean, the opposition is getting more and more anticlerical.

The election of the majority PiS government from 2015, the sharp right turn in Polish politics, and the weakness of centre-left has galvanised new inclusive opposition movements in Poland. In part, these have built on earlier networks and organisations. In the case of the nonreligious, these developed in the wake of the first PiS led administration (2005-7); inspired by the 'Out Campaign' for atheists to publicly declare their position led by British God Delusion

\footnotetext{
${ }^{1}$ Evidence in this section is drawn from interviews conducted by a project led by the author from 2018-2019.

'Reaching for a new sense of connection? Towards a deeper understanding of the sociality of generation $Y$ non-believers in northern and central Europe' The project was made possible through a grant from the John Templeton Foundation (JTF grant ID\#60624) based at the University of Kent. Josh Bullock conducted the interviews on the project. Twelve interviews were carried out in locations across Poland as part of the project.
} 
author Richard Dawkins, List of Internet Atheists and Agnostics was established in 2007, followed by Internet Photo Atheists in 2009.

In response to the 2012 formation of a Parliamentary Group for Prevention of Atheism in Poland actions were launched by the Polish Association of Rationalists in 2012 under the slogan 'If you don't believe you are not alone'. This was followed in 2013 by an Atheists' March in Warsaw, which commemorated the 'martyrdom' of the 'first Polish Atheist' Kazimierz Łyszczyński in 1689. Subsequently, an annual event nominating and celebrating the 'Biggest Atheist in Poland' recognising individuals, organisations and institutions for counteraction against discrimination based on belief has been held as well as "atheist picnics" (Bullock and Bullivant, forthcoming). While not directly combatting the influence of the far right, such groups provide networks which enable mobilisation when the government threatens to further exclude minorities from the public sphere, or further erode their rights or the rights of women.

\section{Conclusion}

This article we have sought to address four research questions. First, what is the influence and effect of right-wing populism across key social fields in Polish society, especially on the rights and lives of immigrants, religious minorities, and LGBT groups? While right wing populism has been a phenomenon in Polish society over a long period, right wing groups have been empowered by the election of the PiS in 2005-7, and further so since 2015. This has highlighted the vulnerability of minority groups, who have experienced increased intimidation as standards of civility in the public sphere have declined following the example of politicians, and physical attacks have become more frequent. While official Catholic teaching is clear on the need to extend hospitality to refugees this has been undermined by populist mobilisations of religion by multiple media sources, and while some elements of open Catholicism, especially in the press, have challenged these developments, other leaders and elements in popular Catholicism have supported and fed them.

What, then, is the role of religion in these struggles from an analytic standpoint? In particular, is the PCC ('institutional religion') complicit in the growth of RWP's influence and its' othering practices, or is RWP mobilisation more the result of 'discursive religion' operating in the public sphere beyond church control, disseminated by religiously self-identified parachurch groups or media outlets, like the RM group, Fronda.pl or Polonia Christiana? On issues where official Catholic teaching is unequivocally contrary to a radical right position, like hospitality to refugees or interfaith relations, the picture seems to be one of church leaders struggling to bring institutions like RM under control - but being undermined by support from other quarters within the episcopate. On gender equality and sexuality issues where official teaching is socially conservative, and the Bishops' Council statements tend towards the conservative end of interpreting this teaching, there is less of a check on radical right populist appropriation of religion.

In their insightful analysis of the discourse of the Polish bishops on gender issues, Szwed and Zieleńska argue that rather than seeing issues such as reproduction, violence against women, IVF, abortion and gay sexuality as part of the private sphere of individual rights:

[T] hese issues are treated by religious actors as a matter of public or national concern. Therefore, in the Church's discourse, the rights of the family or community (i.e. nation) to thrive and survive 
gain priority over the individual rights of women (e.g. to decide about their health and body) and men (e.g. to have protection in their private life in the case of gay men). (2017: 126)

In these social fields then, there is a closer alignment between right wing populist construction of a homogenous nation and a conservative interpretation of Catholic teaching, and hence, more of an enabling role of the PCC in the growing influence of RWP in these fields.

Third, what has caused the increase in right wing religious populism across these social fields in Poland? We have reviewed a range of possible causes, from Poland's history of division and occupation making frames of heroic national martyrdom and international victimisation particularly resonant, through to job insecurity for many in the population. Drawing on Göle's theory of visibility as agency, it may be suggested that in this context of insecurity changes in the public sphere (such as the construction of mosques and the advent of Pride parades) may be experienced as cultural 'invasions' which make it easier to activate these national frames. Certainly, the role of the internet and social media, where for example $86 \%$ (compared to $55 \%$ for Catholic magazines and newspapers) of the sample in one national survey say they obtain their information on Islam and Muslims, is also a significant enabling factor (Pędziwiatr 2018: 471).

Finally, opposition groups have responded with increased co-operation across a range of issues thorough common interest groups, achieving success in the case of resisting proposals for further restrictions on abortion. We have also observed pragmatic responses at city level, for example to immigration, which suggest the possibility of developing and implementing progressive policies despite the position of the national government, in a development that parallels the deepening of multicultural and equalities practices in diverse cities in the UK in the 1980s and 1990s despite a right wing government; however, such disparities in national practice risk reinforcing existing divisions and polarisation. The future is therefore uncertain, with opposition groups increasingly networked and organised to resist further shifts right and long term demographics favouring the decline of Catholic nationalism; but it is difficult to see how escalating cultural conflict can be avoided in the medium term.

\section{REFERENCES}

Bilewicz, Michal, Mikołaj Winiewski, Mirosław Kofta, and Adrian Wójcik. 2013. "Harmful Ideas, The Structure and Consequences of Anti-Semitic Beliefs in Poland". Political Psychology 34(6): 821-839. doi: https://doi.org/10.1111/pops.12024.

Bobako, Monika. 2018. "Semi-peripheral Islamophobias: the political diversity of anti-Muslim discourses in Poland". Patterns of Prejudice 52(5): 448-460. doi: https://doi.org/10.1080/0031322X.2018.1490112.

Bujalski, Szymon. 2016. “Polska walczy z obcymi. Rośnie liczba ataków rasistowskich i ksenofobicznych”. Gazeta Wyborcza. http://wyborcza.pl/1,75398,20699634,polska-walczy-zobcymi-rosnie-liczba-atakowrasistowskich-i.html (Date of retrieval: 11 October 2019).

Bullivant, Stephen. 2018. Europe's young adults and religion, Paris: Institute Catholique de Paris.

Bullock, Josh and Stephen Bullivant. "Nonreligion and Europe". In The Oxford Handbook of Religion and Europe edited by Leustean, Lucian, Davie, Grace, forthcoming. OUP: Oxford.

CBOS. 2011. Dwadzieścia Lat Radia Maryja. Centrum Badania Opinii Społecznej. BS/168/2011. Warszawa.

Cienski, Jan. 2017. “Why Poland doesn't want refugees”. Politico. http://www.politico.eu/article/politicsnationalism-and-religion-explain-why-poland-doesnt-want-refugees/. (Date of retrieval: 11 October 2019). 
Dehnel, Jacek. 2019. “The struggle for LGBT equality: Pride meets prejudice in Poland". The Guardian https://www.theguardian.com/world/2019/jul/28/lgbt-gay-rights-poland-first-pride-marchbialystok-rage-violence (Date of retrieval: 28 July 2019).

ESS - European Social Survey. 2014. ESS round 7: European Social Survey round 7 data. Norwegian Centre for Research Data. http://www.europeansocialsurvey.org/data/download.html?r=7. (Date of retrieval: 11 October 2019).

Eurostat. 2014. "Eurostat labour market and labour force survey". http://ec.europa.eu/eurostat/ statisticsexplained/index.php/Labour market and Labour force survey \%28LFS\%29 statistics. (Date of retrieval: 11 October 2019).

Fras, Maksymilian Zbigniew. 2009. The Catholic Church, Religion and Politics in Post-Communist Poland: Secularisation and Republicisation 1989-2007. PhD thesis, Open University.

Godzisz Piotr, and Paweł Knut. 2018. LGBTI rights in Poland: Measures to combat discrimination and violence on grounds of sexual orientation, gender identity and sex characteristics, Strasbourg: Council of Europe. https://tgeu.org/wp-content/uploads/2018/10/COE-Report-Oct18-poland 1.pdf(Date of retrieval: 10 December 2019).

Göle, Nilüfer. 2012. "The public visibility of Islam and European politics of resentment: The minarets-mosques debate". Philosophy \& Social Criticism 37(4): 383-392. Doi: https://doi. org/10.1177/0191453711398773.

Hall, Bogumila. 2019. “Gendering Resistance to Right-Wing Populism: Black Protest and a New Wave of Feminist Activism in Poland?". American Behavioral Scientist 63(10): 1497-1515. doi: https://doi. org/10.1177/0002764219831731.

Herbert, David 2003. Religion and Civil Society: Rethinking Public Religion in the Contemporary World, Aldershot: Ashgate.

Herbert David. 2013. Creating Community Cohesion: Religion, Media and Multiculturalism in North Western Europe, London: Palgrave Macmillan.

Herbert David and Hansen Janna. 2018. "'You are no longer my flesh and blood': Social Media and the Negotiation of a Hostile Media Frame by Danish 'Reverts' to Islam". Nordic Journal of Religion and Society 31 (1): 4-21. doi: https://doi.org/10.18261/issn.1890-7008-2018-01-01.

Kubik, Jan. 1994. The Power of Symbols Against the Symbols of Power: The Rise of Solidarity and the Fall of State Socialism in Poland, Philadelphia: Pennsylvania University Press.

Krzemiński, Ireneusz. 2017. "Radio Maryja and Fr. Rydzyk as a Creator of the National Catholic Ideology". In Religion, Politics, and Values in Poland: Continuity and Change Since 1989 edited by Ramet, Sabina, Borowik, Irene, 85-112. New York: Palgrave Macmillan. doi: https://doi.org/10.1057/978-1137-43751-8 5 .

Marcianak, Katarzyna. 2009. "Post-Socialist hybrids". European Journal of Cultural Studies, 12(2): 173-190. doi: $\underline{\text { https://doi.org/10.1177/1367549409102424. }}$

Marcinkiewicz. Kamil. 2016. "Der politische Rechtsruck in Polen: Analyse von Ursachen und außenpolitischen Konsequenzen". Z Außen Sicherheitspolit 9: 463-476. doi: 10.1007/s12399-016-0591-z.

Narkowicz, Kasia and Konrad Pędziwiatr. 2017. "Why are Polish people so wrong about Muslims in their country?". OpenDemocracy. https://www.opendemocracy.net/can-europe-make-it/ kasia-narkowiczkonrad-pedziwiatr/why-are-polish-people-so-wrong-about-muslims-in. (Date of retrieval: 11 October 2019). 
Narkowicz, Kasia. 2018. “Refugees Not Welcome Here': State, Church and Civil Society Responses to the Refugee Crisis in Poland". International Journal of Political Culture and Society 31(2): 357-373. doi: https://doi.org/10.1007/s10767-018-9287-9.

Noack, Rick. 2019. "Polish cities and provinces declare 'LGBT-free zones' as government ramps up 'hate speech'”. The Independent. https://www.independent.co.uk/news/world/europe/poland-lgbtfree-zones-homophobia-hate-speech-law-justice-party-a9013551.html. (Date of retrieval: 11 October 2019).

Pędziwiatr, Konrad. 2017. "Islamophobia in Poland: National Report 2016". In European Islamophobia report 2016, edited by Bayralki, Enes, Hafez, Farid, 411-443. Istanbul: SETA.

Pędziwiatr, Konrad. (2018) 'The Catholic Church in Poland on Muslims and Islam', Patterns of Prejudice, 52:5, 461-478. doi: https://doi.org/10.1080/0031322X.2018.1495376.

O’Dwyer, Conor, and Schwartz, Kartina Z. S. 2010. “Minority rights after EU enlargement: A comparison of antigay politics in Poland and Latvia". Comparative European Politics 8(2): 220-243. doi: https://doi. org/10.1057/cep.2008.31.

Osa, Maryjane. 1997. "Creating solidarity: The religious foundations of the Polish social movement". East European Politics and Societies 11(2): 339-365. doi: https://doi.org/10.1177/0888325497011002007.

OSCE. 2017. "Hate Crime Reporting". OSCE/ODIHR. http://hatecrime.osce.org/poland?year=2017. (Date of retrieval: 20 September 2019).

Pawlik, Wojciech. 1995. "The Church and its Critics: the Spell of the Polish Ombudsman". Polish Sociological Review 109(1): 31-45.

Reuters. 2019. "Polish rights campaigners gather in Warsaw to condemn homophobic violence". https://www.reuters.com/article/us-poland-lgbt/polish-rights-campaigners-gather-in-warsaw-tocondemn-homophobic-violence-idUSKCN1UM0FS. (Date of retrieval: 20 September 2019).

Szelegieniec, Paweł. 2018. "Behind the 'Black Protests': The Struggle for Abortion Rights in Poland". Monthly Review 70(1): 45-59. doi: https://doi.org/10.14452/MR-070-01-2018-05 5.

Szpak, Agnieszka. 2019. "How to deal with migrants and the State's backlash - Polish cities' experience". European planning studies 27(6): 1159-1176. doi: https://doi.org/10.1080/09654313. $\underline{2019.1569598 .}$.

Szwed Anna and Zieleńska Katarzyna 'A War on Gender: the Roman Catholic Church's Discourse in Poland' in Ramet, S and Borowik, I (eds.) Religion, Politics, and Values in Poland: Continuity and Change Since 1989 New York : Palgrave Macmillan, 113-136.

World Data Atlas. 2019. "Poland -Gini Index". https://knoema.com/atlas/Poland/GINI-index. (Date of retrieval: 20 September 2019). 